\title{
IESKATS REFORMĀCIJAS GADSIMTA BAZNİCAS MŪZIKĀ RĪGĀ
}

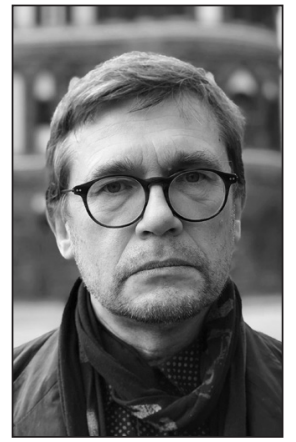

Vilis Kolms (1964) ir Mg. art. mūzikas pedagogiijā (Jāzepa Vītola Latvijas Valsts konservatorija, 1983-1989), ieguvis baznīcmūzikas specialitāti B līmenī Greifsvaldes Universitātes Baznīcas mūzikas institūtā (1993-1995), kur joprojām ir doktorants (kopš 2001). Kopš 1991. gada pasniedzis liturǵikas, himnologijas un liturǵiskās dziedāšanas kursus LU Teoloǵijas fakultātē, ir tās liturǵikas docētājs (kopš 2011) un bakalaura studiju programmas Baznīcas mūzika direktors Lutera Akadēmijā (kopš 2013). Raksti vācu valodā par vēsturisko luteriskās baznīcas mūziku un liturğiju Rīgā.
Raksturvārdi: baznīcas mūzika, liturǵija, reformācija, dievkalpojums, Andreass Knopkens, Pauls Bucens.

\section{Reformācijas mūzikas specifika}

Mūzika, kas veidojas un attīstās luteriskās reformācijas ietvaros, formas, satura un lietojuma ziṇā pilnā mērā iekḷaujas vispārējā Baznīcas tradīcijā. Tā ir veidojusies kā dievkalpojuma (mesas, stundu lūgšanas u. c.) medijs. Melodijas uzdevums ir izcelt dievkalpošanas tekstus un vienot tās dalībniekus Dieva klātbūtnes svinēšanā un lūgšanā. Tomēr reformācijas laikā baznīcas mūzika iegūst arī jaunus akcentus, kurus vispirmām kārtām var raksturot kā muzicēšanas, resp., dziedāšanas, tuvināšanos tautai. Sapulcētās draudzes dziedājumi dievkalpojumā pirms reformācijas ieņem vēl visai pieticīgu vietu, un galvenā nozīme ir kora dziedājumiem latīnu valodā, kamēr līdz ar reformāciju sāk pieaugt visas draudzes kopīgo dziesmu un dziedājumu skaits un tie dievkalpošanā iegūst konstituējošu nozīmi. Dievkalpojuma "nesēja" nu ir ne tikai garīdzniecība viena pati, kuru atbalsta vairāk vai mazāk profesionāls koris, bet gan visa draudze kopā. Šis fakts tiek uzskatīts par ievērojamu reformācijas veiksmes cēloni, jo luteriskās draudzes dziesmas un mūzika būtiski veicināja atjaunotās teologijas nokḷūšanu cilvēku prātos un sirdīs.

\section{Burkhards Valdiss (ap 1490-1556)}

Pirmā saglabātā liecība par luteriskās baznīcas mūzikas sākumiem Rīgā atrodama dramaturgískā uzvedumā divos cēlienos $L \bar{l}$ dzība par pazudušo dēlu (izdots Kēnigsbergā 1527. gadā). Uzveduma autors ir Burkhards Valdiss (Burkhard Valdis), luteriskajā ticībā pārgājis franciskāṇu ordeņa brālis. Tā titullapā norādīts, ka darbs ticis uzvests Rīgā 1527. gada 17. februārīi . Savai dzejai Valdiss

1 De parabell vam vorlorn Szohn \| Luce am $\tilde{x}$. gespelet vnnd Christlick gehandelt || nha ynnholt des Texts / ordentlick na dem || geystliken vorstande sambt aller $v m \sim=\|$ stendicheit vthgelacht / Tho || Ryga ynn Lyfflandt / Am \| xvij. dage des Monts \|| Februarij. \| M. D.xxvij. 


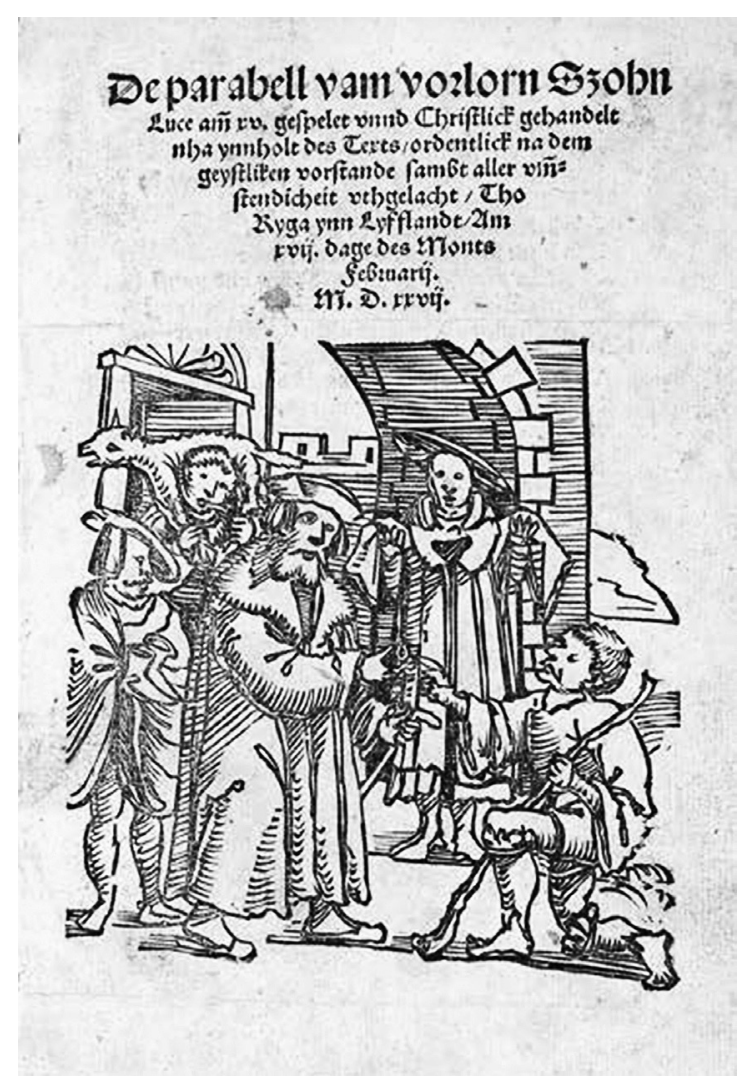

1. attēls. Lìdz̄̄bas par pazudušo dèlu titullapa.

Hercoga Augusta bibliotēka, Wolfenbüttel, LO:7812

pievienojis Mārtina Lutera (Martin Luther) un Andreasa Knopkena (Andreas Knöpken) dievkalpojumam paredzētas dziesmas, kuras, sekojot uzveduma norisei, ievietotas atbilstošās vietās. Tās paredzēts izpildīit daudzbalsīgam korim, kurš iesaistīts uzveduma norise. ${ }^{2}$ Saskaṇā ar ievadvārdos sacīto autors ar šo uzvedumu vēlējies parādīt, kā evanggêelijs māca cilvēka taisnošanu ar Dieva žēlastību, nevis ar labiem darbiem. Lai gan šis uzvedums nav uzskatāms par dievkalpojumu š̄ vārda šaurākā nozīmē, tomēr tā mērḳis un izveidojums kopā ar luteriskajām draudzes dziesmām lielā mērā atbilst reformācijas dievkalpojuma galvenajam uzdevumam - evangéêlija pasludināšanai tautas valodā visiem saprotamā un piedzīvojamā veidā.

\footnotetext{
2 Arnold 2014.
}

\section{Rīgas dievkalpojuma un dziesmu grāmatas}

Nākamais nozīmīgais posms Rīgas luteriskās baznīcas mūzikas attīstībā sākas līdz ar Rīgas pirmās luteriskās dievkalpojuma un dziesmu grāmatas izdošanu. 1530. gadā Rostokā tiek nodrukāta grāmata İsa Baznīcas kalpošanas kārtība ... ar psalmiem un dievišşām slavas dziesmām, kas tiek dziedātas kristīgās draudzēs R̄̄gă $\bar{a}^{3}$ Lai arī šajā grāmatā vēl ir tikai dziedājumu un dziesmu teksti (dažiem no tiem pievienotas tukšas nošu līnijas,

3 Kurtz Ord $\approx \|$ nung des Kirchen $\approx \|$ diensts / Sampt eyner \| Vorrede von Ceremonien / \|An den Erbarn Rath der löbli $\|$ chenn Stadt Riga ynn \| Liefflandt. \| Mit etlichen Psalmen / || vnd Götlichen lobgesengen / $\|$ die yn Christlicher versamlung || zu Riga ghesungen || werden. \| M.D.XXX. 


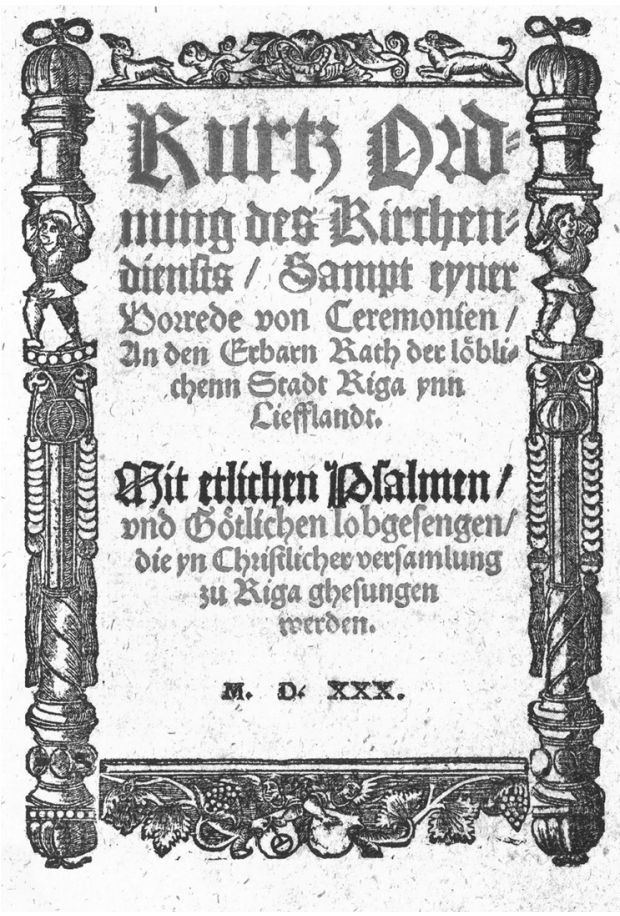

2. attēls. 1530. gada izdevuma titullapa.

Uppsala universitetsbibliotek

(S-Uu) Obr. 49:42 1

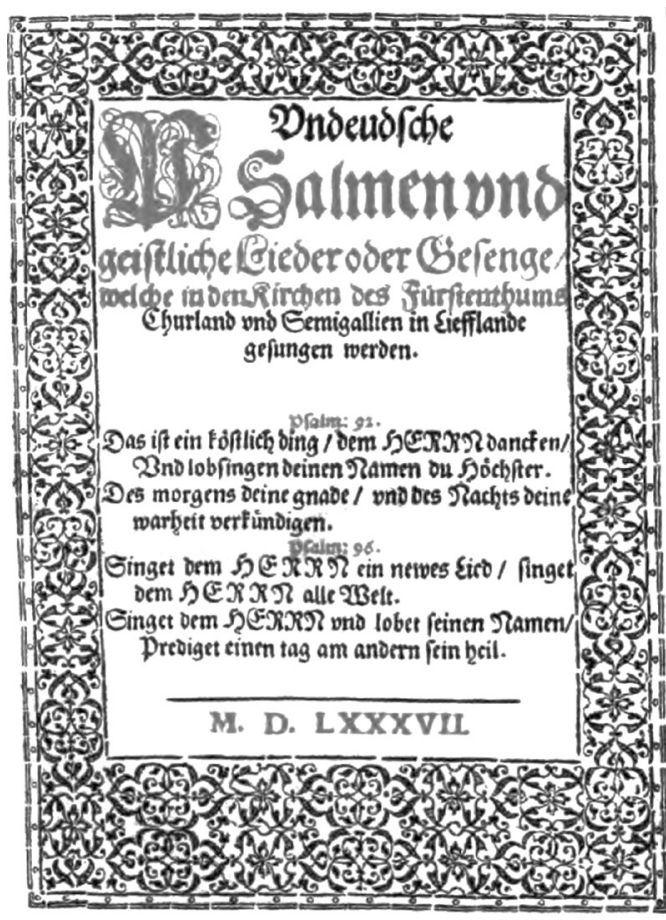

3. attēls. Titullapa 1537. gada izdevumam.

Staatsbibliothek zu Berlin - Preußischer Kulturbesitz, Ms Mus. 40074

pusgadsimtu vēlāk, proti, 1587. gadā, tiek nodrukāta Kēnigsbergā ${ }^{5}$, satur senākus latviešu luteriskā dievkalpojuma dziedājumus, kas radušies varbūt pat reizē ar tiem, kuri atrodami abos pieminētajos Rīgas vācu izdevumos. Šajā pirmajā latviešu dievkalpojuma un dziesmu grāmatā lielākajai daḷai dziesmu un dziedājumu jau bija pievienotas notis.

\section{Andreasa Knopkena (ap 1468-1539) melodijas}

Zīmīgi, ka baznīcas mūzikas iesākums Rīgā un Vidzemē saistāms nevis ar kāda mūziḳa personību, bet gan ar teologa Andreasa Knopkena vārdu. Tas vēlreiz apliecina, cik cieši reformācijas vidē sadarbojas teolog̣ija un mūzika. A. Knopkens ir viens diviem tomēr filologs Pēteris Vanags savā darbā pirmajām latviešu dievkalpošanas grāmatām ${ }^{4}$ sniedz pārliecinošus argumentus, ka pirmā latviešu dievkalpošanas rokasgrāmata, kas

4 Vanags 2000.
5 Undeudsche \| Psalmen vnd $\|$ geistliche Lieder oder Gesenge, \|| welche in den Kirchen des Fürstenthums || Churland vnd Semigallien in Liefflande \| gesungen werden. \| M.D.LXXXVII. 


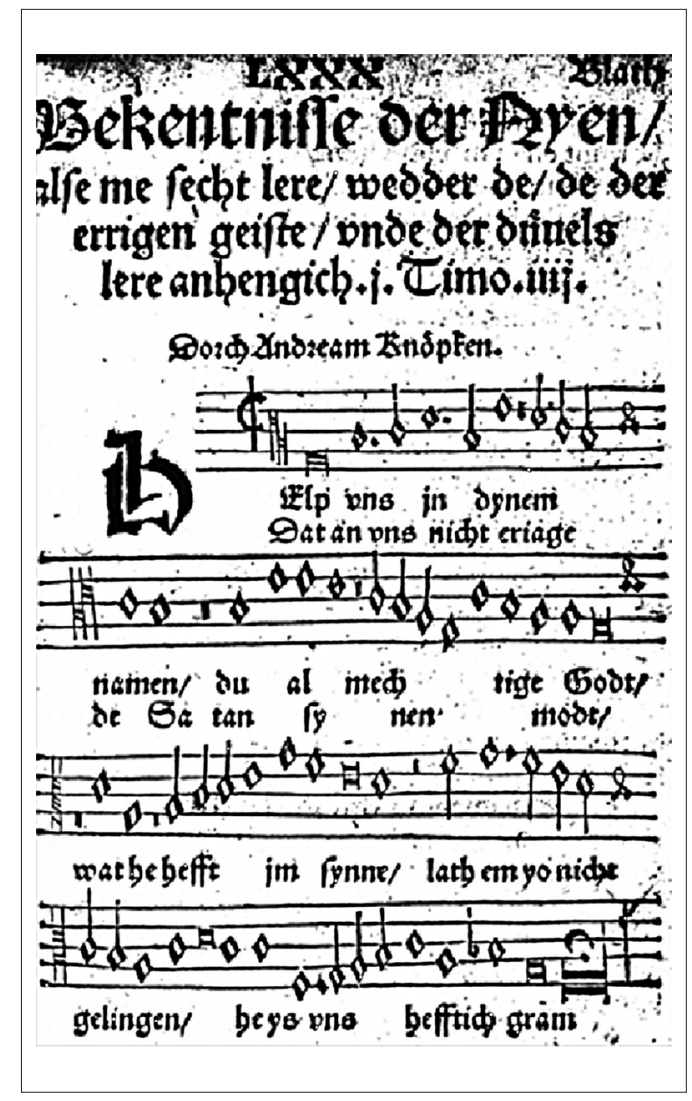

4. attēls. Lappuse ar A. Knopkena dziesmu no 1537. gada izdevuma pirmajiem reformācijas apustuḷiem Rīgā (blakus Sv. Jēkaba draudzes mācītājam Silvestram Tegetmeieram), kurš atbilstoši reformācijas teologiiskajām atziniām vada draudzi Rīgas Sv. Pētera baznīcā jau kopš 1522. gada. Vispusīgã izglîtīiba l̦auj A. Knopkenam ne vien sniegt pārliecinošu teoloǵisku argumentāciju par labu reformācijai (vina skaidrojums Vēstulei romiešiem un 1522. gada disputam paredzētās 24 tēzes Kaspara Bankovska tulkojumā nesen tika izdotas latviski' ${ }^{6}$, bet arī ar panākumiem darboties praktiski - veidot draudzes dievkalpošanu ne tikai ar M. Lutera un citu autoru tekstu un dziesmu palīdzīibu, bet arī ar paša sarakstītiem dziesmu tekstiem un melodijām.

A. Knopkena melodijas, iespējams, nav reformācijas gadsimta ievērojamākie mūzikas šedevri, tomēr tajās pamanāms skaidrs autora rokraksts. Vācbaltiešu mūzikas vēsturnieks Elmārs Arro savā nepublicētajā monogrāajijā ${ }^{7}$ raksta, ka A. Knopkena dziesmas melodijas ziņā lıoti atšķiras no tipiskiem luterāṇu korāļiem un drīzāk būtu uzskatāmas par dziesmām vai pat dziedājumiem; tajās nevar pamanīt raksturīgo tuvumu tautasdziesmām vai pazīstamu laicīgu dziesmu atskaṇas. Kā iespējamo

\footnotetext{
6 Vēstules romiešiem skaidrojums 2017.

7 Arro b. g.
}

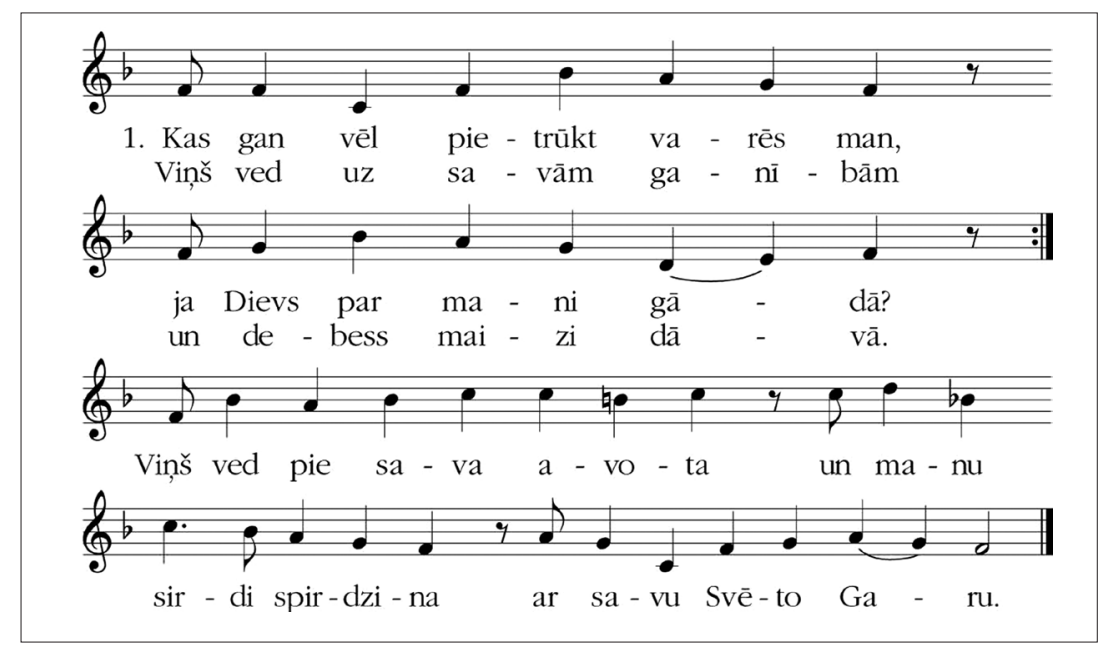

5. attēls. LELB Dziesmu grāmata (2015), dziesma Nr. 473 
iemeslu šādai A. Knopkena dziesmu atšksirībai no tradicionālā luterāṇu korāḷ E. Arro min vietējas vācbaltiešu tautas mūzikas tradīcijas trūkumu un varbūtējus iespaidus no kādām mūsdienās vairs nepazīstamām Rīgā dziedātām himnām. Tomēr šādi minējumi jāuztver piesardzīgi. Neapšaubāmi var runāt par Rīgas lokālo tradīciju vēl pirms reformācijas (par to liecina, piem., Latvijas Mūzikas akadēmijas rektora prof. Guntara Prāṇa disertācija par 15. gs. Rīgas dziedājumiem ${ }^{8}$ ), tomēr nav ziṇu par kādām specifiskām intonatīvi origínālām vietējām himnām. Turklāt A. Knopkens Rīgā ir tikai ienācējs, kurš nav dzimis un audzis vācbaltiešu vidē. Svarīgi šḳiet arī tas, ka šajā laikā luteriskā korāḷa tradīcija vēl tikai pamazām iezīmējas un veidojas. Tāpēc nav gluži atbilstoši sacīt, ka A. Knopkena korāḷmelodijas neatbilst tradīcijai; drīzāk būtu jāatzīst, ka A. Knopkens ar vina īpatnējo muzikālo pieeju ir Baltijas korāḷtradīcijas līdzveidotājs. Taisn̄̄ba E. Arro tomēr ir tajā ziṇā, ka A. Knopkena teksti ir pārāki par viņa melodijām, un arī 2017. gadā izdotajā Latvijas Evanggéēiski luteriskās baznīcas Dziesmu grāmată $\bar{a}^{9}$ atjaunotā tulkojumā vina dziesma Kas gan vēl pietrūkt varēs man ievietota nevis ar autora oriǵinālo, bet gan ar M. Lutera melodiju.

\section{Pauls Bucens (1548-1586)}

Pārskatu pār reformācijas gadsimta baznīcas mūziku Rīgā vēlos noslēgt ar ieskatu Paula Bucena (Paulus Bucenus) darbos. P. Bucens var tikt uzskatīts par pirmo profesionālo Rīgas un Vidzemes baznīcmūziḳi un komponistu. Par viņa dzīvi pirms nokḷūšanas Rīgā zināms maz. Par studijām Greifsvaldes Universitātē liecina 1568. gada ieraksts matrikulā, ka viṇš imatrikulēts bez maksas. ${ }^{10}$ P. Bucena komponētā Mateja pasija (Passio Domini nostri Jesu Christi secundum Mattheum) izdota Štetīnē (tag. Ščecina) 1578. gadā, kamēr pārējās vairāk nekā 150 kompozīcijas tapušas Rīgā, kur viņš strādāja par Doma baznīcmūzikị. Darbu skaits

\footnotetext{
8 Prānis 2015.

9 LELB Dziesmu grāmata 2015, 534-535.

10 Paulus Bucenus, philorhodus, Holsata, musicus, qui in artis musices honorem gratis est inscriptus. Engels 1929, 10.
}

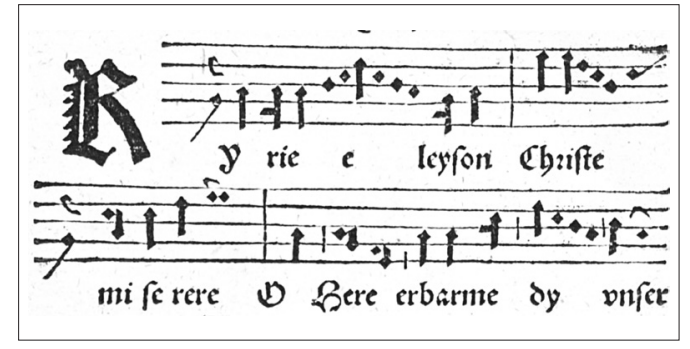

6. attēls. Kyrie no 1537. gada izdevuma

un nosaukumi zināmi no 1931. gadā izdotās P. Bucena biogrāfijas, kuras autors, vācbaltu komponists, dirigents un kritikis Gerhards fon Koislers, ir rūpīgi pētījis viña dzīvi un darbī$b^{11}$. Daudzas viņa kompozīcijas gājušas bojā Otrā pasaules kara laikā, bet daḷa rokrakstu atrodami Berlīnē ${ }^{12}$.

P. Bucena dailı̆rade pamatā apkopota 1583.-1584. gadā radītajā manuskriptā Opus musicae ecclesiae rigensis. Tas sastāvēja no divām daḷām un saturēja norādījumu, ka skaṇdarbi domāti atskaņošanai Rīgas baznīcā svētku dienās un visa liturǵiskā gada ciklā. Šìm kompozīcijām piemīt ne vien muzikāla, bet arī kultūrvēsturiska vērtība - tā kā tās aptver veselu liturgískā gada ciklu un ir paredzētas tieši lietošanai in ecclesia Rigensi, no š̄ manuskriptu krājumā atrodamā repertuāra, no skaņdarbu izveidojuma un no to vietas liturǵijā var daudz spriest par tā laika mūzikas un dievkalpošanas dzīvi Rīgā, īpaši Rīgas Domā, kur P. Bucens darbojās. Šī darbu krājuma abu daḷu virsraksti ${ }^{13}$ liecina, ka Rīgā reformācijas gadsimta otrajā pusē jau praktizēta izkopta

11 Keussler 1931.

12 Staatsbibliothek zu Berlin - Preußischer Kulturbesitz, Ms Mus. 40074.

13 TOMUS PRIMUS: Sacrae aliquot cantiones sex vocum ad tria contrapuncti genera accomodatae musicis scholisquae aptissimae decantatae; Sacrae aliquot cantiones quinque et quatuor vocum ad tria contrapuncti genera accomodatae musicis instrumentis scholisquae aptissimae decantatae. TOMUS SECUNDUS: Missae aliquot quatuor, Quinque, sex et octo vocum ad clarissimorum musicorum motetas et sacros quosdam tenores accomodatae; Preces vespertine (responsoria, hymni, Magnificat et aliae quaedam cantiones quae in p'cipuis diebus festis et totum annum in Ecclesia Rigensi decantantur quinque et sex vocibus concinnatae). 
vokāla daudzbalsība līdz pat astoṇām balsīm un šo skaņdarbu atskaņošanā tikuši iesaistīti arī dažādi mūzikas instrumenti. Svētdienas dievkalpojumi bieži notikuši ar latīṇu valodā atskaņotiem mesas dziedājumiem.

P. Bucena darbu krājumā atrodamas 24 mesas, no kurām tikai viena ir tautas valodā. Lai arī latīṇu valodā, tomēr viņa mesas atšķiras no tradicionālajām Romas katoḷu mesām. Tās ir īpašas gan ar to, ka vairākās iestarpināti pazīstamu korāḷu daudzbalsīgi salikumi, gan ar to, ka nevienā no tām neietilpst tradicionālā mesas daḷa Credo (Ticības apliecība), jo tās vietā visa draudze dziedāja Lutera korāli Wir glauben all (Uz Dievu Tēvu ticam mēs). Mesās izmantotas arī pazīstamu gregorisku dziedājumu intonācijas un apdarināti citāti no viņa laikabiedru komponētām motetēm. ${ }^{14}$

24 mesu vidū viena izcel̦as ar nosaukumu Missa Rigaensis, kas vien̄̄gā ir tautas valodā. Šāds nosaukums, visticamāk, pieškirts tāpēc, ka tā tieši balstîta uz iepriekš pieminēto Rīgas dievkalpošanas kārtību. Raksturīga iezīme šai mesai ir, piem., tās īpatnējais Kyrie izveidojums. Šajā Romas mesas ordinarium dziedājumā lietotā valoda ir grieķu (nevis latīņu): Kyrie eleison, Christe eleison, Kyrie eleison. Toties saskan̄ā ar Rīgas luteriskās mesas kārtību tas tiek dziedāts trīs valodās - griekisiski, latīniski un tautas valodā: Kyrie eleyson, Christe miserere, O Here erbarme dy vnser. Melodisko izveidojumu iespaidojis Kyrie dziedājums no 13. gs. gregoriskās mesas Firmator sancte. Bez svētdienas un svētku dievkalpojumiem notikušas arī vakara lūgšanas, par ko liecina fakts, ka ievērojama daļa (31) no P. Bucena rokrakstu krājumā atrodamajiem darbiem pieder pie vesperu repertuāra (responsoriji, himnas, Magnificat).

Rūpīgi meklējot, P. Bucena daiḷradē var pamanīt arī pavisam cita rakstura kultūrvēsturiskās pēdas. Viṇa komponētajā motetē, kas balstās uz pazīstamo M. Lutera korāli Dievs, savu vārdu uzturi, komponists izmainījis tekstu saskaņā ar vietējo politisko situāciju. Cik grūti mūsdienās šķiet pieņemams M. Lutera oriǵināls (latviešu tulkojumā tā asums arvien mīkstināts līdzīgi, kā tas notika arī š̄̄s dziesmas vēlākās versijās oriǵginālvalodā), tik

${ }^{14}$ Leszczyńska 2016, 94. vēl jo vairāk tas attiecas uz P. Bucena veikto korekciju.

\section{Mārtiñš Luters:}

Erhalt uns Herr bei Deinem Wort

und steure Pabst' und Türken Mord.

\section{Pauls Bucens:}

Erhalt uns, Herr, bei Deinem Wort und steur' des Pabsts und Russen Mord. ${ }^{15}$

M. Luters šo tekstu rada īpašā, izmisuma pilnā ǵeopolitiskā situācijāâ, kad turku karaspēks stāvēja Vīnes pievārtē un visa Rietumeiropa draudēja nonākt turku impērijas pakḷautībā. Līdzịgu apdraudējumu 16. gs. beigās Vidzemē piedzīvo P. Bucens, kad Rīga 1582. gadā nonāca Polijas-Lietuvas valdīšanā, bet vairāki Vidzemes pierobežas apgabali uz laiku tika pievienoti Krievijai. Par to, kā šis fakts tika uznemts Rīgā, liecību sniedz P. Bucena kompozīcijas teksts.

\section{Baznīcas mūzika kā doksoloğija}

Vācu luterāṇu teologs Dr. Reinhards Slencka savās dogmatikas lekcijās norāda, ka dievatziņa veidojas nevis no jēdzienu un priekšstatu attīstīšanas, bet no Dieva slavēšanas un apliecināšanas un no pateicības Dievam $^{16}$. Luteriskā baznīcas mūzika ir tā, kas ticīgajiem palīdz formulēt Dieva slavu vārdos un melodijā un vieno tos pateicībā Dievam. Dievkalpojuma mūzika līdz ar to kḷūst par līdzekli, kā sistemātiskai teologijai pārtapt par praktisku, kḷūstot par doksologiju. Tāpēc arī luteriskās baznīcas mūzikas attīstība uzskatāma par reformācijas neizbēgamām sekām un reizē savā ziņā arī par priekšnoteikumu tās teoloǵiskajiem panākumiem.

Mūzikas uzplaukums Rīgas draudzēs, kas pievērsās reformācijai, reizē liecina arī par

${ }^{15}$ Kungs, uzturi mūs pie sava Vārda un iznīcini Pāvestu un turkus. (M. Luters)

Kungs uzturi mūs pie sava Vārda un iznīcini Pāvestu un krievus. (P. Bucens)

${ }^{16}$ Gotteserkenntnis vollzieht sich nicht in der Entwicklung von Begriffen oder in der Vermittlung von Vorstellungen, sondern darin, daß Gott als Gott gepriesen, bekannt und ihm gedankt wird. Slenczka 1997/1998. 
luteriskās teologíjas ievērojamo vietu rīdzinieku dzīvē. Jaunie un atjaunotie dievkalpojuma teksti, jaunais liturǵiskais konteksts, luteriskie korāḷi un draudzes aktīvā piedalīšanās dievkalpojuma norisē - šie reformācijas gadsimta ieguvumi l̦āva baznīcas mūzikai ne vien sasniegt jaunu kvalitāti, bet arī paplašināt tās izpildītāju bāzi ar vienkāršajiem draudzes locekḷiem. Tādā veidā luteriskā baznīcas mūzika kḷūst arī par ievērojamu spēku tautas estētiskās uztveres kopšanā un lasītprasmes veicināšanā, jo tautā iecienīto dziesmu apgūšana vieglāk veicās, ja tika apgūta spēja lietot grāmatas, kur tās iespiestas.

Luteriskais korālis kḷūst par baznīcas mūzikas atjaunošanas un attīstības vadošo elementu ne vien tautas dziedātajās dievkalpojuma dziesmās, bet arī - ja tā to var dēvēt - profesionālajā mūzikā. Būtiski ir tieši tas, ka melodijas un teksti, kas atskan mesās, daudzbalsīgās motetēs, vēlākos gadsimtos arī vokāli simfoniskās kantātēs un oratorijās, daudzos gadījumos ir paz̄istami korāḷi, kurus klausītāji paši dzied un ar kuros izsacītajām ticības patiesībām tie pilnībā spēj identificēties.

Rīgā un Vidzemē reformācijas pirmajos gadsimtos š̄ attīstība vairāk attiecināma uz vācu draudzēm, taču vēlāk tā atstāj pēdas arī latviešu mūzikas kultūrā. Ne velti viens no būtiskākajiem impulsiem ceḷā uz pirmajiem Vispārējiem latviešu dziesmu svētkiem ir koru kustība, kuras pirmsākumi vispirms meklējami vācbaltiešu un drīz pēc tam arī latviešu luteriskajās draudzēs.

\section{VĒRES}

Arnold, M. (2014) Burkhard Valdis als thelologischer Schriftssteller. Zeitschrift für Hessische Geschichte und Landeskunde, Bd. 119, S. 36 ff.

Arro, E. (b. g.) Geschichte der baltischen Kirchenmusik und geistlichen Tonkunst. Manuskripts mašīnrakstā Igaunijas Mūzikas un teātra akadēmijas (Eesti Muusika- ja Teatriakadeemia) arhīvā Tallinā. Õ-13000/I.

Engels, H. (1929) Musik und Musikleben in Greifswalds Vergangenheit. Greifswald.

Keussler, G. von (1931) Paulus Buceanus. Riga : Verlag der Buchhandlung G. Löffler.

Latvijas evanğèeliski luteriskās Baznīcas Dziesmu grāmata (2015) Rīga.

Leszczyńska, A. (2016) Liturgical Function and Gregorian Chant in the Music of Paulus Bucenus. Musicologica Brunensia, 51, 1.

Prānis, G. (2015) Rīgas misāles dziedājumi viduslaiku Eiropas gregorisko tradīciju kontekstā. Promocijas darbs. Rīga : Jāzepa Vītola Latvijas Mūzikas akadēmija.

Slenczka, R. (1997/1998) Dogmatik im Überblick. Vorlesung von Prof. Dr. Reinhard Slenczka. Erlangen. Vanags, P. (2000) Luterāņu rokasgrāmatas avoti. Stockholm/Riga.

Vēstules romiešiem skaidrojums, ko kistrinietis Andreass Knopkens ir priekšlasījis livoniešiem Rīgāa, kur viņš ir draudzes gans. 24 tēzes disputam 1522. gadā Sv. Pētera baznīcā (2017) Rīga. 